Dermatology 2010;220:282-286

DOI: $10.1159 / 000277928$

\section{Infliximab for the Treatment of Refractory Adamantiades-Behçet Disease with Articular, Intestinal, Cerebral and Ocular Involvement}

\section{Davide Donghi, Carlo Mainetti}

Department of Dermatology, Ospedale Regionale di Bellinzona e Valli, Bellinzona, Switzerland

\section{Key Words}

Adamantiades-Behçet disease $\cdot$ Monoarthritis $\cdot$ Oral and genital ulcerations - Ileocaecal bleeding $\cdot$ Cerebral vasculitis • HLA-B51 • Retinal vasculitis • Infliximab

Adamantiades-Behçet disease (ABD) is a chronic relapsing multisystem inflammatory vascular disorder with a broad spectrum of clinical manifestations, some of them being associated with high morbidity and mortality [1-4]. Tumour necrosis factor $\alpha(\mathrm{TNF}-\alpha)$ is a potent pro-inflammatory cytokine playing an important role in the pathogenesis of several inflammatory diseases, including $\mathrm{ABD}$ [4-7]. Therefore, TNF- $\alpha$-inhibiting therapy has been used successfully for severe and/or acute cases of ABD [729].

We report a case of ABD presenting with bipolar aphthous lesions, relapsing monoarthritis, cerebral vasculitis and complicated by haemorrhagic terminal ileitis resulting in potentially lifethreatening anaemia. The clinical course was refractory to a corticosteroid-and azathioprine-based immunosuppressive therapy with appearance of retinal vasculitis despite treatment. A complete, lasting remission was achieved with infliximab (IFX).

\section{Case Report}

In spring 2003, a 17-year-old young man of Albanian (Kosovo) origin started to complain about recurrent swelling and pain in his left knee; he was taken in charge by a rheumatologist who ruled out an infectious agent as well as a collagenosis by performing several joint punctures and serological tests. HLA-B27 was negative.

The monoarthrits showed further relapses, which led to a radiosynoviorthesis in May 2004, and finally to a surgical synoviectomy in January 2007. Four days after discharge from the orthopaedic clinic, the patient was referred to our Department because of very painful scrotal necrotic lesions, which started to appear as he came back home after knee surgery. At clinical examination, 2 distinct ulcerative lesions were present on the scrotum, with diameters of 4 and $5 \mathrm{~cm}$, central necrosis, fibrin-rich ground and elevated borders (fig. 1a). A sexually transmitted disease was ruled out. Haematological analysis showed microcytic hypochromic anaemia ( $\mathrm{Hb} 10.7 \mathrm{~g} / \mathrm{dl}$ ) and elevation of C-reactive protein at $81 \mathrm{mg} / \mathrm{dl}$, without leucocytosis. An empirical antibiotic treatment with amoxicillin/clavulanic acid, $1 \mathrm{~g}$ twice daily, was started. Histological examination of a skin biopsy specimen taken on an ulcer border described dermal massive neutrophilic infiltration without granulomas. Giemsa, Warthin-Starry and Gram staining showed no presence of bacteria, hence also excluding donovanosis.

After targeted asking, the patient mentioned more than $10 \mathrm{ep}$ isodes of painful oral ulcerations starting to appear about 13 months before the genital lesions, thus leading to suspicion of ABD. Clinical, neurological and ophthalmological assessment was normal. Considering its prognostic value $[2,30]$, we ordered an HLA-B51 test, with a positive result. Colchicine $0.5 \mathrm{mg}$ twice daily was started.

Persistent headache motivated a cerebral magnetic resonance scan (fig. 1c) which was consistent with focal (micro)vasculitis. Following the revised criteria for the diagnosis of ABD [2], the diagnosis of incomplete ABD could be formulated after detection of cerebral involvement. Lumbar puncture permitted to rule out infectious encephalomeningitis and multiple sclerosis. Cardioangiological assessment including echocardiography, ECG, arterial Doppler sonography of the lower extremities, cyclo-ergometry and magnetic resonance angiography of the whole aorta was normal.

Five days after hospitalization, the patient developed abdominal pain with abundant bloody diarrhoea and rapidly worsening anaemia ( $\mathrm{Hb}$ from 10.5 to $6.9 \mathrm{~g} / \mathrm{dl}$ in 4 days). Endoscopy evidenced deep ileocaecal mucosal ulcerations (fig. 1b) with massive arterial bleeding after biopsy, requiring haemostasis with a metallic clip. Histological analysis showed a neutrophilic non-granulomatous infiltration, hence excluding Crohn's disease. This acute manifestation led us to introduce a middle-dosed immunosuppressive treatment, administering intravenous methylprednisolone $125 \mathrm{mg}$ twice daily for 3 days and then switching to oral prednisone $50 \mathrm{mg} /$ day. We added oral azathioprine $150 \mathrm{mg}$ daily and a primary vascular prevention with acetylsalicylic acid 100 mg daily. Eight weeks later, cerebral magnetic resonance imaging showed total regression of the cerebral vasculitic lesions.

Prednisone was slowly tapered: in September 2007, the patient still had oral prednisone $15 \mathrm{mg}$ daily, azathioprine $150 \mathrm{mg}$ once and colchicine $0.5 \mathrm{mg}$ twice daily. Two weeks later, the patient reported a right superior central scotoma and visus loss. Funduscopy and retinal angiography supported the diagnosis of retinal artery vasculitis (fig. 1d). Prednisone was increased to $50 \mathrm{mg}$ daily, and the administration of IFX ( $5 \mathrm{mg} / \mathrm{kg}$ as slow intravenous infusion) was started. Two days later all ophthalmological symptoms had completely resolved, as confirmed by retinal angiography. IFX was repeated every 6 weeks until September 2008 without drug-induced complications, then every 7 weeks until March 2009 and finally every 8 weeks, while slowly decreasing prednisone to $10 \mathrm{mg} /$ day and keeping azathioprine at $150 \mathrm{mg}$ daily. At present, no further relapses of $\mathrm{ABD}$ were observed, including mucosal and skin manifestations. 

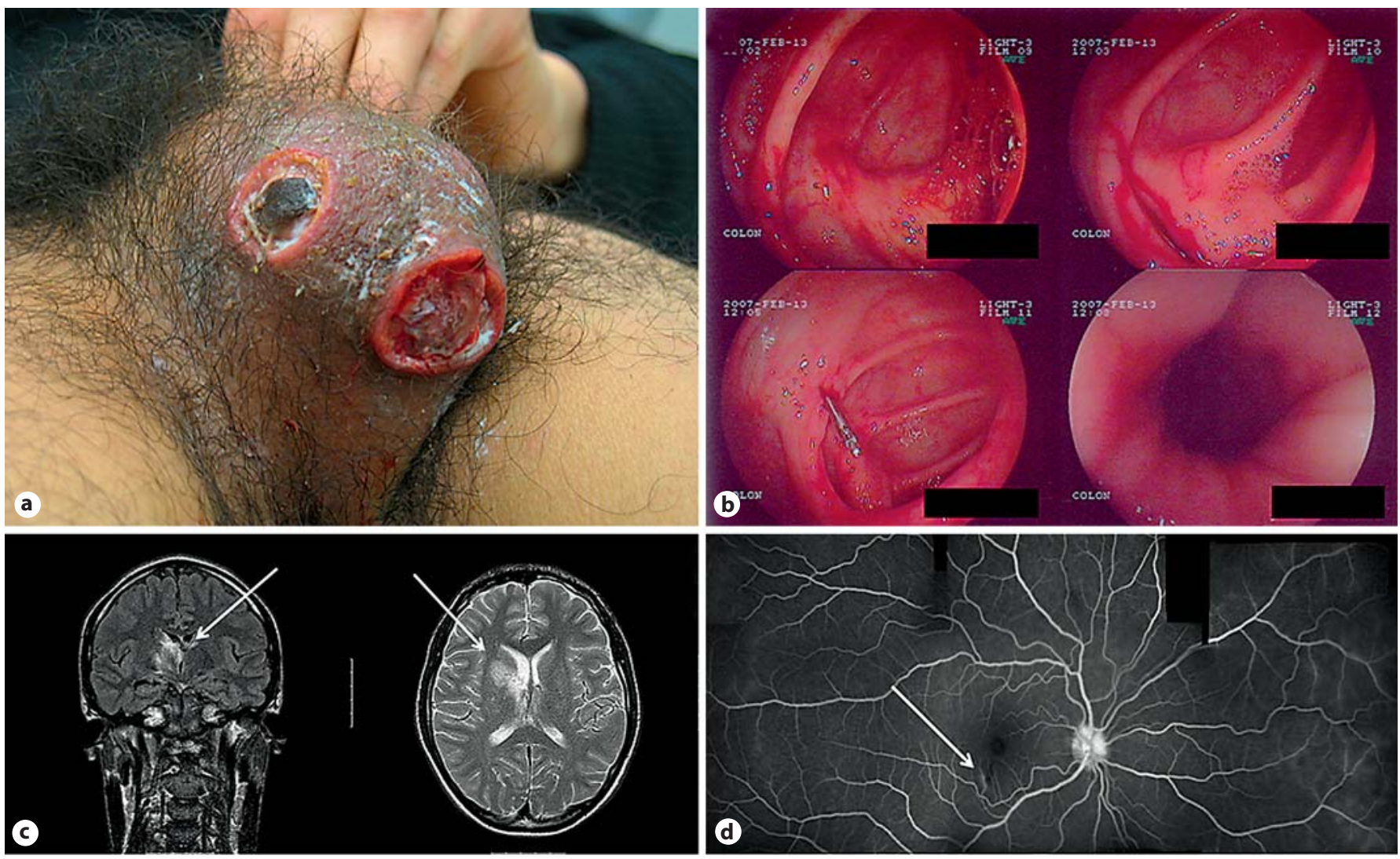

Fig. 1. a Painful ulcerative lesions on the scrotum. b Endoscopy: ileocaecal mucosal ulcerations, with metallic clip after biopsy. c Cerebral magnetic resonance imaging: enhancement in the periventricular region (arrows), predominantly on the right side and in the basal ganglion region. $\mathbf{d}$ Retinal angiography of the right eye: typical setting of retinal artery vasculitis (arrow).

\section{Discussion}

$\mathrm{ABD}$ is a Th1-mediated chronic relapsing multisystem inflammatory vascular disease of complex, yet not entirely known aetiopathogenesis $[2,4,5]$. As summarized by Kalayciyan and Zouboulis [4] in 2007, there seems to be a vasculitic reaction where IgM-type anti-endothelial cell antibodies [31], heat shock proteins, Toll-like receptors, IL-12, IL- 8 and $\gamma \delta$ T lymphocytes are involved, in a setting of different immune responses to environmental antigens such as commensal or pathogenic micro-organisms or to self-antigens [4,32]. After being first described by Hippocrates of Kos [33], the disease was defined by the Greek ophthalmologist Benedict Adamantiades [34] in 1931 and subsequently in 1937 by the Turkish dermatologist Hulusi Behçet [35] as a triad of uveitis, oral and genital ulcerations. The prevalence is predominant in the countries along the ancient silk route [36] (hence the old description 'silk route disease' [37]), namely from Japan and the Turkmen areas in Mongolia through the Middle East to Turkey and Greece, with current epidemiological data suggesting a clear genetic background [38]. It remains an essential clinical entity, not being associated with any elevation of an auto-antibody titre; the current diagnostic criteria accepted worldwide were established in 1990 by the International Study Group for ABD, based on a multicentric study on 914 patients from 12 centres in 7 countries [1], and have recently been revised [2]. This disease can also affect the gastro-intestinal tract (mimicking Crohn's disease), the cardiovascular system, the joints, the kidneys and the central nervous system (neuro-ABD) [1-3, 36].

For mucosal and skin involvement, the treatment is essentially based on colchicine. Thalidomide, dapsone and $\alpha$-interferon are good alternatives. Systemic corticosteroids associated with other immunosuppressive agents (most often azathioprine) are necessary in case of ocular or other extramucosal involvement. Treatment alternatives include cyclophosphamide and cyclosporine $A[2,7,36]$. In 2007, after reviewing the literature, Sfikakis et al. [7] formulated general recommendations for the use of IFX in $\mathrm{ABD}$, defining posterior segment intra-ocular inflammation as the only indication for IFX as first-line treatment. Currently, there are no official guidelines regarding treatment regimen and duration, with reported cases ranging from a single dose to a total of 30 , for a maximal duration of 5 years. Table 1 summarizes the published cases of acute and/or severe ABD treated with IFX [829 ] and shows how satisfactory the response to the TNF- $\alpha$ inhibitor is, with 76/99 patients experiencing complete remission, 15 patients with partial remission and only 8 patients showing no response. Further, IFX has also been reported as a successful 
Table 1. Reported cases of severe and/or acute ABD treated with IFX

\begin{tabular}{|c|c|c|c|c|c|c|}
\hline Authors & Year & $\begin{array}{l}\text { Number } \\
\text { of patients }\end{array}$ & $\begin{array}{l}\text { Major } \\
\text { involvement }\end{array}$ & Regimen & $\begin{array}{l}\text { Number of doses/duration of } \\
\text { treatment }\end{array}$ & Outcome \\
\hline $\begin{array}{l}\text { Muñoz-Fernández } \\
\text { et al. [9] }\end{array}$ & 2001 & 1 & ocular & $5 \mathrm{mg} / \mathrm{kg}$ & $3 / 6$ weeks & marked, lasting improvement \\
\hline Sfikakis et al. [10] & 2001 & 5 & ocular & $5 \mathrm{mg} / \mathrm{kg}$ & 1 & complete remission \\
\hline Takamoto et al. [11] & 2007 & 1 & ocular & $\begin{array}{l}10 \mathrm{mg} / \mathrm{kg} \text {, then } \\
5 \mathrm{mg} / \mathrm{kg}\end{array}$ & 14 and 30 , resp. $/ 5$ years & $\begin{array}{l}\text { complete remission, recurrence after } \\
\text { discontinuation }\end{array}$ \\
\hline $\begin{array}{l}\text { Benitez-del-Castillo } \\
\text { et al. [13] }\end{array}$ & 2005 & 5 & ocular & $5 \mathrm{mg} / \mathrm{kg}$ & $3-8 / 6$ weeks to 21 months & complete, lasting remission in $100 \%$ \\
\hline Sayarlioglu et al. [14] & 2004 & 1 & ocular & $5 \mathrm{mg} / \mathrm{kg}$ & $8 / 10$ months & complete, lasting remission \\
\hline Sfikakis et al. [15] & 2004 & 25 & ocular & $5 \mathrm{mg} / \mathrm{kg}$ & 1 & complete remission in $100 \%$ \\
\hline Olivieri et al. [19] & 2009 & 1 & ocular & $5 \mathrm{mg} / \mathrm{kg}$ & $13 / 22$ months & complete, lasting remission \\
\hline Al-Rayes et al. [20] & 2008 & 10 & ocular & $5 \mathrm{mg} / \mathrm{kg}$ & $2 / 2$ weeks & $\begin{array}{l}\text { complete lasting remission in } 30 \% \text {; } \\
\text { recurrence in } 70 \% \text {, with complete remission } \\
\text { after beginning of scheduled infusions every } \\
8 \text { weeks }\end{array}$ \\
\hline Lee et al. [21] & 2007 & 1 & intestinal & $5 \mathrm{mg} / \mathrm{kg}$ & $2 / 4$ weeks & complete, lasting remission \\
\hline $\begin{array}{l}\text { Naganuma } \\
\text { et al. [22] }\end{array}$ & 2008 & 6 & intestinal & $5 \mathrm{mg} / \mathrm{kg}$ & $\begin{array}{l}3 / 6 \text { weeks, then every } \\
6-8 \text { weeks in } 4 \text { patients; } \\
3 / 6 \text { weeks in } 1 \text { patient; } \\
1 \text { in } 1 \text { patient }\end{array}$ & $\begin{array}{l}\text { complete, lasting remission } \\
\text { no response } \\
\text { no response }\end{array}$ \\
\hline Ju et al. [23] & 2007 & 1 & intestinal & $300 \mathrm{mg}$ & 1 & complete remission \\
\hline Licata et al. [28] & 2003 & 1 & CNS & $5 \mathrm{mg} / \mathrm{kg}$ & $3 / 6$ weeks & complete remission \\
\hline Pipitone et al. [29] & 2008 & 8 & CNS & $5 \mathrm{mg} / \mathrm{kg}$ & $\begin{array}{l}3 / 3-6 \text { weeks, then every } \\
6-8 \text { weeks in } 7 \text { patients; } \\
3 / 6 \text { weeks in } 1 \text { patient }\end{array}$ & $\begin{array}{l}\text { marked improvement in } 6 \text { patients; } \\
\text { complete, lasting remission in } 1 \text { patient; } \\
\text { complete, lasting remission in } 1 \text { patient }\end{array}$ \\
\hline
\end{tabular}

treatment option in refractory pyoderma gangrenosum [39, 40], thus underlining its effectiveness in neutrophilic processes.

The clinical course of ABD is mostly unpredictable, with possible relapses even despite adequate therapy. The main cause of morbidity and disability is visus loss following uveitis, and possible lethal outcomes can be the consequence of arterial thrombosis and aneurysm rupture [41], as well as intestinal bleeding.

The reported case exhibits several of the typical complications mentioned in ABD. Monoarthritis was the only symptom during the first 3 years: joint involvement represents the initial manifestation in about $7 \%$ of patients with ABD [42] and has proved to be associated with delayed diagnosis in the absence of other suggestive symptoms [43]. This case bears an epidemiological interest, as this is the fourth ever reported patient with ABD originating from Kosovo [44]. The lack of reported cases is even more surprising if we consider the neighbourhood of Kosovo and Albania with countries with a high prevalence, namely Greece, Turkey, Italy and Serbia. This fact, in addition to the severe course in the reported Albanian patients, could indicate that ABD is still 'unknown' in the country or that less severe cases could be misdiagnosed. Further, neuro-ABD is a rarely diagnosed manifestation but it could be underestimated, if cerebral radiological imaging is 
not performed $[3,24,25,45]$. Last, this case emphasizes the unpredictability of $\mathrm{ABD}$ even with combined immunosuppression (development of an ocular involvement despite therapy) and corroborates the evidence of efficacy and a favourable safety profile of TNF- $\alpha$ inhibitors in the treatment of ABD refractory to conventional immunosuppressive drugs, as already reported by other authors. Whether the absence of recurrence is due to a protective effect of IFX or to the natural course of the disease remains unclear. Furthermore, many questions still remain unanswered regarding the total duration of TNF- $\alpha$-inhibitor-based treatment; unfortunately, there are currently no protocols that could solve this problem. We think that large-scale, long-term studies are surely needed to establish accepted guidelines for this kind of treatment of ABD.

\section{Acknowledgements}

The authors would like to thank PD Dr. G. Kaya, Dr. S. LeoniParvex, Dr. C. Gaia, Dr. P. Pedrazzi, Dr. O. Bernasconi, Dr. A. Menafoglio and Dr. G. Mariotti for their precious cooperation.

\section{References}

1 International Study Group for Behçet's Disease: Criteria for diagnosis of Behçet's disease. Lancet 1990;335:1078-1080.

2 Zouboulis CC: Adamantiades-Behçet disease; in Wolff K, Goldsmith LA, Katz SI, Gilchrest BA, Paller AS, Leffell DJ (eds): Fitzpatrick's Dermatology in General Medicine, ed 7. New York, McGraw Hill, 2008, pp $1620-1626$.

3 Akman-Demir G, Serdaroglu P, Tasci B: Clinical patterns of neurological involvement in Behçet's disease: evaluation of 200 patients. The Neuro-Behçet Study Group. Brain 1999;122:2171-2182.

4 Kalayciyan A, Zouboulis CC: An update on Behçet's disease. J Eur Acad Dermatol Venereol 2007;21:1-10.

$\checkmark 5$ Evereklioglu C, Er H, Türkoz Y, Cekmen M: Serum levels of TNF- $\alpha$, sIL-2R, IL-6, and IL-8 are increased and associated with elevated lipid peroxidation in patients with Behçet disease. Mediators Inflamm 2002; 11:87-93.

6 Sfikakis PP: Behçet's disease: a new target for anti-tumour necrosis factor treatment. Ann Rheum Dis 2002;61(suppl):ii51-ii53.

7 Sfikakis PP, Markomichelakis N, Alpsoy E, Assaad-Khalil S, Bodaghi B, Gul A, Ohno S, Pipitone N, Schirmer M, Stanford M, Wechsler B, Zouboulis C, Kaklamanis P, Yazici H: Anti-TNF therapy in the management of Behçet's disease - review and basis for recommendations. Rheumatology (Oxford) 2007;46:736-741.

${ }_{8}$ Baki K, Villiger PM, Jenni D, Meyer T, Beer JH: Behçet’s disease with life-threatening haemoptoe and pulmonary aneurysms: complete remission after infliximab treatment. Ann Rheum Dis 2006;65:15311532.

-9 Muñoz-Fernández S, Hidalgo V, Fernández-Melón J, Schlincker A, Martín-Mola E: Effect of infliximab on threatening panuveitis in Behçet's disease. Lancet 2001;358:1644.

10 Sfikakis PP, Theodossiadis PG, Katsiari CG, Kaklamanis P, Markomichelakis NN: Effect of infliximab on sight-threatening panuveitis in Behçet's disease. Lancet 2001;358:295-296.

-11 Takamoto M, Kaburaki T, Numaga J, Fujino Y, Kawashima H: Longterm infliximab treatment for Behçet's disease. Jpn J Ophthalmol 2007; $51: 239-240$

12 Niccoli L, Nannini C, Benucci M, Chindamo D, Cassarà E, Salvarani C, Cimino L, Gini G, Lenzetti I, Cantini F: Long-term efficacy of infliximab in refractory posterior uveitis of Behçet's disease: a 24-month follow-up study. Rheumatology (Oxford) 2007;46:1161-1164.

-13 Benitez-del-Castillo JM, Martinez-de-la-Casa JM, Pato-Cour E, Méndez-Fernández R, López-Abad C, Matilla M, Garcia-Sanchez J: Longterm treatment of refractory posterior uveitis with anti-TNFalpha (infliximab). Eye 2005;19:841-845.
14 Sayarlioglu M, Cinal A, Topcu N, Demirok A: Effect of infliximab on refractory uveitis in Behçet's disease. Ann Pharmacother 2004;38:901-902.

15 Sfikakis PP, Kaklamanis PH, Elezoglou A, Katsilambros N, Theodossiadis PG, Papaefthimiou S, Markomichelakis N: Infliximab for recurrent, sight-threatening ocular inflammation in Adamantiades-Behçet disease. Ann Intern Med 2004;140:404-406.

16 Lanthier N, Parc C, Scavennec R, Dhôte R, Brézin AP, Guillevi L: Infliximab in the treatment of posterior uveitis in Behçet's disease: longterm follow-up in four patients. Presse Méd 2005;34:916-918.

17 Tognon S, Graziani G, Marcolongo R: Anti-TNF-alpha therapy in seven patients with Behçet's uveitis: advantages and controversial aspects. Ann NY Acad Sci 2007;1110:474-484.

18 Olivieri I, Latanza L, Siringo S, Peruz G, Di Iorio V: Successful treatment of severe Behçet's disease with infliximab in an Italian Olympic athlete. J Rheumatol 2008;35:930-932.

$\checkmark 19$ Olivieri I, Padula A, Leccese P, D’Angelo S, Giasi V: Long-lasting remission of severe Behçet's disease after the end of infliximab therapy. J Rheumatol 2009;36:855.

20 Al-Rayes H, Al-Swailem R, Al-Balawi M, Al-Dohayan N, Al-Zaidi S, Tariq M: Safety and efficacy of infliximab therapy in active Behçet's uveitis: an open-label trial. Rheumatol Int 2008;29:53-57.

21 Lee JH, Kim TN, Choi ST, Jang BI, Shin KC, Lee SB, Shim YR: Remission of intestinal Behçet's disease treated with anti-tumor necrosis factor alpha monoclonal antibody (infliximab). Korean J Intern Med 2007; 22:24-27.

22 Naganuma M, Sakuraba A, Hisamatsu T, Ochiai H, Hasegawa H, Ogata $\mathrm{H}$, Iwao Y, Hibi T: Efficacy of infliximab for induction and maintenance of remission in intestinal Behçet's disease. Inflamm Bowel Dis 2008; 14:1259-1264.

$23 \mathrm{Ju}$ JH, Kwok SK, Seo SH, Yoon CH, Kim HY, Park SH: Successful treatment of life-threatening intestinal ulcer in Behçet's disease with infliximab: rapid healing of Behçet's ulcer with infliximab. Clin Rheumatol 2007;26:1383-1385.

24 Ribi C, Sztajzel R, Delavelle J, Chizzolini C: Efficacy of TNF $\alpha$ blockade in cyclophoshamide resistant neuro-Behçet disease. J Neurol Neurosurg Psychiatry 2005;76:1733-1735.

25 Kikuchi H, Aramaki K, Hirohata S: Effect of infliximab in progressive neuro-Behçet's syndrome. J Neurol Sci 2008;272:99-105.

26 Fujikawa K, Aratake K, Kawakami A, Aramaki T, Iwanaga N, Izumi Y, Arima K, Kamachi M, Tamai M, Huang M, Nakamura H, Nishiura Y, Origuchi T, Ida H, Eguchi K: Successful treatment of refractory neuroBehçet's disease with infliximab: a case report to show its efficacy by magnetic resonance imaging, transcranial magnetic stimulation and cytokine profile. Ann Rheum Dis 2007;66:136-137.

27 Sarwar H, McGrath H Jr, Espinoza LR: Successful treatment of longstanding neuro-Behçet's disease with infliximab. J Rheumatol 2005;32: 181-183.

28 Licata G, Pinto A, Tuttolomondo A, Banco A, Ciccia F, Ferrante A, Triolo G: Anti-tumour necrosis factor alpha monoclonal antibody therapy for recalcitrant cerebral vasculitis in a patient with Behçet's syndrome. Ann Rheum Dis 2003;62:280-281.

29 Pipitone N, Olivieri I, Padula A, D’Angelo S, Nigro A, Zuccoli G, Boiardi L, Salvarani C: Infliximab for the treatment of neuro-Behçet's disease: a case series and review of the literature. Arthritis Rheum 2008; 59:285-290.

-30 Zouboulis CC, Turnbull JR, Martus P: Univariate and multivariate analyses comparing demographic, genetic, clinical, and serological risk factors for severe Adamantiades-Behçet's disease. Adv Exp Med Biol 2003;528:123-126.

31 Lee KH, Chung HS, Kim HS, Oh SH, Ha MK, Baik JH, Lee S, Bang D: Human alpha-enolase from endothelial cells as a target antigen of antiendothelial cell antibody in Behçet's disease. Arthritis Rheum 2003;48: 2025-2035.

32 Zouboulis CC, Turnbull JR, Mühlradt PF: High seroprevalence of antiMycoplasma fermentans antibodies in patients with malignant aphthosis. J Invest Dermatol 2003;121:211-212. 
33 Feigenbaum A: Description of Behçet's syndrome in the Hippocratic third book of endemic diseases. Br J Ophthalmol 1956;40:355-357.

34 Adamantiades B: Sur un cas d'iritis à hypopyon récidivant. Ann Oculist (Paris) 1931;168:271-278.

35 Behçet H: Über rezidivierende, aphthöse, durch ein Virus verursachte Geschwüre am Mund, am Auge und an den Genitalien. Dermatol Wochenschr 1937;105:1152-1157.

36 James DG: 'Silk route disease' (Behçet's disease). West J Med 1988;148: 433-437.

37 Ohno S, Ohguchi M, Hirose S, Matsuda H, Wakisaka A, Aizawa M: Close association of HLA-Bw51 with Behçet's disease. Arch Ophthalmol 1982;100:1455-1458.

38 Papoutsis NG, Abdel-Naser MB, Altenburg A, Orawa H, Kötter I, Krause L, Pleyer U, Djawari D, Stadler R, Wollina U, Kohl PK, Gollnick HP, Kirch W, Ochsendorf FR, Keitel W, Martus P, Zouboulis CC: Prevalence of Adamantiades-Behçet's disease in Germany and the municipality of Berlin: results of a nationwide survey. Clin Exp Rheumatol 2006;24(suppl 42):S125 (erratum published in Clin Exp Rheumatol 2007;25:507-508).

- 39 Adişen E, Oztaş M, Gürer MA: Treatment of idiopathic pyoderma gangrenosum with infliximab: induction dosing regimen or on-demand therapy? Dermatology 2008;216:163-165.

40 Juillerat P, Christen-Zäch S, Troillet FX, Gallot-Lavallée S, Pannizzon RG, Michetti P: Infliximab for the treatment of disseminated pyoderma gangrenosum associated with ulcerative colitis. Dermatology 2007; 215:245-251.
Arishiro K, Nariyama J, Hoshiga M, Nakagawa A, Okabe T, Nakakoji T, Negoro N, Ishihara T, Hanafusa T: Vascular Behçet's disease with coronary artery aneurysm. Intern Med 2006;45:903-907.

42 Al-Otaibi LM, Porter SR, Poate TW: Behçet's disease: a review. J Dent Res 2005;84:209-222.

43 Zouboulis CC, Kötter I, Djawari D, Kirch W, Kohl PK, Ochsendorf FR, Keitel W, Stadler R, Wollina U, Proksch E, Söhnchen R, Weber H, Gollnick HP, Hölzle E, Fritz K, Licht T, Orfanos CE: Epidemiological features of Adamantiades-Behçet's disease in Germany and in Europe. Yonsei Med J 1997;38:411-422.

44 Hoxha FT, Hashani S, Krasniqi A, Pllana M, Komoni D, Pustina B, Sopa $\mathrm{R}$, Zouboulis CC: Intestinal vasculitis in Adamantiades-Behçet disease presenting as acute abdomen. J Eur Acad Dermatol Venereol 2009; 23:1461-1463.

45 Aykutlu E, Baykal B, Akman-Demir G, Topcular B, Ertas M: Headache in Behçet's disease. Cephalalgia 2006;26:180-186.

Dr. Carlo Mainetti

Primario Servizio Cantonale di Dermatologia

Ospedale Regionale di Bellinzona e Valli

CH-6500 Bellinzona (Switzerland)

Tel. +41 91811 8989, Fax +41918118681

E-Mailinfo@carlomainetti.ch 